\title{
PENERAPANMODEL PEMBELAJARAN KUANTUM UNTUK MENINGKATKAN PRESTASIBELAJAR DALAMMENULIS CERITA PENDEK PADASISWA KELAS VIII ESMP NEGERI 1 DENPASARTAHUN PELAJARAN 2016/2017
}

\author{
Ni Nyoman Nerti \\ Guru Bahasa Indonesia SMP Negeri 1 Denpasar
}

\begin{abstract}
ABSTRAK
Penelitian ini dilaksanakan di SMP Negeri 1 Denpasar di Kelas VIII E Semester 2 yang kemampuan siswanya dibidang mata pelajaran Bahasa Indonesia dalam Menulis Cerita Pendek masih rendah. Tujuan penulisan penelitian tindakan kelas ini adalah untuk mengetahui apakah penerapan model pembelajaran Kuantumdapat meningkatkan prestasi belajar siswadibidang mata pelajaran Bahasa Indonesia dalam Menulis Cerita Pendek. Metode pengumpulan datanya adalah tes prestasi belajar. Metode analisis datanya adalah deskriptif.Hasil yang diperoleh dari penelitian ini tentang Penerapanmodel pembelajaran Kuantum dapat meningkatkan prestasi belajar Bahasa Indonesia dalam Menulis Cerita Pendek pada Siswa kelas VIII E Semester 2 Tahun Pelajaran 2016/2017. Pencapaian kenaikan prestasi belajar siswa dapat dilihat dari bukti-bukti berikut:a).Dari data awal ada 27 siswa mendapat nilai dibawah KKM dan pada siklus I menurun menjadi 15 siswa dan siklus II hanya 3 siswa mendapat nilai di bawah KKM. b). Dari rata-rata awal 75,78 naik menjadi 79,62 pada siklus I danpada siklus II naik menjadi83,57. c).Dari data awal siswa yang tuntas hanya 10 siswa sedangkan pada siklus I menjadi lebih banyak yaitu 22 siswa dan pada siklus II menjadi cukup banyak yaitu 34 siswa.Kesimpulan yang diperoleh dari penelitian ini adalah Penerapan Model Pembelajaran Kuantum dapat meningkatkan prestasi belajar Bahasa Indonesia dalam Menulis Cerita Pendek pada Siswa Kelas VIIIE Semester 2 SMP Negeri 1 Denpasar Tahun Pelajaran 2016 / 2017
\end{abstract}

Kata kunci : Pembelajaran Kuantum, Prestasi Belajar, Menulis Cerita Pendek

\section{ABSTRACT}

This study aims to improve the Pedagogical Competence of Class IV Teachers of SD Negeri 9 Dauh Puri and the ability of teachers to prepare RPP in the Learning Process by applying Academic Supervision. This type of research is school action research and involves 1 teacher at the Dauh Puri 9 Elementary School in the academic year 2016/2017.The data of this study include pedagogic competency data collected using worksheets for assessment instruments for the implementation of learning and the ability to develop learning implementation plans using planning instruments for learning activities. Furthermore, the data collected in this study was analyzed using descriptive statistics. The results showed that there was an increase in Pedagogic Competence and Ability to Arrange RPP. This is evident from the results obtained in the $1.70 \%$ cycle for preparing lesson plans and $73.33 \%$ for pedagogical competencies. From cycle I to cycle II it increased $100 \%$ for the preparation of RPP and 100\% for pedagogic competencies. The conclusion obtained from this study is that academic supervision can improve the pedagogical competence of the teacher and develop a plan for implementing learning.

Keywords: Pedagogic Competence and Academic Supervision 


\section{PENDAHULUAN}

Bahasa Indonesia adalah bahasa persatuan yaitusebagai alat yang digunakan untuk mempersatukan berbagai suku yang tinggal di beberapa pulau. Karena pentingnya fungsi dan peran Bahasa Indonesia sebagai alat pemersatu bangsa maka dalam proses transformasi budaya ke generasi selanjutnya dalam Kurikulum Pendidikan bahasa Indonesia mulai diajarkan sejak usia dini.

Pada proses pembelajaran bahasa Indonesia sangat mengandalkan penggunaan metode-metode yang aplikatif dan menarik. Pembelajaran yang menarik akan memikat peserta didik untuk terus dan betah mempelajari Bahasa Indonesia sebagai bahasa ke-2 setelah bahasa ibu. Apabila siswa sudah tertarik dengan pembelajaran maka akan dengan mudah meningkatkan prestasi siswa dalam bidang bahasa. Di sebagian siswa, pembelajaran Bahasa Indonesia sangat membosankan karena mereka sudah merasa bisa dan penyampaian materi yang kurang menarik sehingga secara tidak langsung siswa menjadi lemah dalam penangkapan materi tersebut. Penulis sebagai guru Bahasa Indonesia sangat merasakan problem pembelajaran yang terjadi selama ini. Terbukti dari hasil pengamatan awal prestasi belajar Bahasa Indonesia siswa baru mencapai rata-rata 75,78 .Nilai ratarata ini masih sangat rendah dibandingkan dengan nilai KKM mata pelajaran Bahasa Indonesia di sekolah ini yaitu 80,00. Hanya 10 orang dari 37 siswa di kelas VIII E yang mencapai tingkat penguasaan materi sesuai harapan. Oleh sebab itu, peneliti berusaha melakukan perubahanperubahan dalam pembelajaran Bahasa Indonesia di dalam kelas. Salah satu perubahan yang dilakukan dengan menggunakanpenerapan model pembelajaran Kuantum untuk mendorong keaktifan siswa dalam belajar dengan cara memberikan kesempatan bagi siswa untuk siap tampil dihadapan teman-temannya seperti berbicara, usaha-usaha guru untuk pencapaian tujuan yang direncanakan, usaha guru untuk mengetahui setiap usaha siswa, usaha guru untuk merayakan keberhasilan siswa, usaha guru untuk mewujudkan percepatan belajar, mempermudah belajar siswa.

Dalam pembelajaran Bahasa Indonesia dapat memakaipenerapan model pembelajaran Kuantum sebagai kegiatan memacu peserta didik memahami bahasa dengan cara diskusi kelompok. Teori Kuantum merupakan metode yang menekankan kepada kerjasama kelompok untuk menyelesaikan sebuah masalah. Dalam model ini, siswa ditempatkan dalam tim belajar beranggotakan empat atau lima orang yang merupakan campuran menurut tingkat prestasi, jenis kelamin, dan suku. Guru menyajikan pelajaran, siswa bekerja dalam tim mereka untuk memastikan seluruh anggota tim telah menguasai pelajaran tersebut. Saat belajar berkelompok, siswa saling membantu untuk menuntaskan materi yang dipelajari. Guru memantau dan mengelilingi tiap kelompok untuk melihat adanya kemungkinan siswa yang memerlukan bantuan guru.

Berdasarkan uraian di atas, judul yang diambil oleh peneliti dalam penelitian ini adalah Penerapan Model Pembelajaran Kuantum dapat meningkatkan prestasi belajar Bahasa Indonesia dalam Menulis Cerita Pendek pada Siswa Kelas VIII E Semester 2 SMP Negeri 1 Denpasar 
Tahun Pelajaran 2016 / 2017. Berdasar rumusan masalah yang telah disampaikan, tujuan penelitian ini dapat disampaikan:Untuk mengetahui seberapa tinggi peningkatan prestasi belajar siswa akan terjadi setelah diterapkan model pembelajaran Kuantumdalam pembelajaran Bahasa Indonesia dalam Menulis Cerita Pendek pada Siswa Kelas VIII E Semester 2 SMP Negeri 1 Denpasar Tahun Pelajaran 2016 / 2017

\section{METODOLOGI PENELITIAN}

Peneliti mengambil lokasi Penelitian Tindakan Kelas ( PTK ) ini di SMP Negeri 1 Denpasar, pada siswa kelas VIII E semester 2 Tahun Pelajaran 2016/2017.yang berlokasi di Jalan Surapati No 2 Denpasar, diharapkan mampu meningkatkan kemampuan menulis cerita pendek.Penelitian yang dilakukan termasuk penelitian tindakan. Oleh karenanya, rancangan yang khusus untuk sebuah penelitian tindakan sangat diperlukan. Penelitian tindakan didasarkan pada filosofi bahwa setiap manusia tidak suka atas hal-hal yang statis, tetapi selalu menginginkan sesuatu yang lebih baik. Peningkatan diri untuk hal yang lebih baik ini dilakukan terus menerus sampai tujuan tercapai (Suharsimi Arikunto, Suhardjono, Supardi, 2006: 6-7).Untuk mengumpulkan data penelitian ini digunakan tes prestasi belajar. Metoda dan Alat Pengumpulan Data Dalam penelitian ini, peneliti menggunakan metode observasi dan metode tes.Metode yang digunakan untuk menganalisis data hasil penelitian ini adalah metode deskriptif. Data yang terkumpul dalam proses pembelajaran pada siklus I dan II dianalisis dengan metode deskriptif, Metode analisis deskriptif adalah cara mengolah data dengan menyusun angka dan persentase tentang variable atau obyek tertentu. Dari hasil analisis ini, tingkat keefektifan dan hasil secara kuantitatif dapat diperoleh dengan kriteria keberhasilan. Kriteria tingkat keberhasilan belajar siswa dengan persen antara lain :

$$
\begin{array}{ll}
>90 \% & : \text { sangat tinggi } \\
80-89 \% & : \text { tinggi } \\
65-79 \% & : \text { sedang } \\
55-64 \% & : \text { rendah } \\
0-54 \% & \text { sangat rendah }
\end{array}
$$

Kriteria tingkat keefektifan pembelajaran siswa dengan persen sebagai berikut :

$$
\begin{array}{ll}
>90 \% & : \text { sangat tinggi } \\
80-89 \% & : \text { tinggi } \\
65-79 \% & : \text { cukup } \\
55-64 \% & : \text { kurang } \\
0-54 \% & \text { sangat rendah }
\end{array}
$$

\section{PEMBAHASAN}

\section{Siklus I}

\section{Rencana Tindakan I}

Hasil yang didapat dari kegiatan perencanaan meliputi:

a. Menyusun RPP mengikuti alur model Sintak Kuantum

b. Menyiapkan bahan-bahan pendukung pembelajaran

c. Membaca teori-teori tentang penerapan model Kuantum untuk dapat dilaksanakan dengan benar di kekas

d. Membuat soal-soal penilaian yang berhubungan dengan kompetensi siswa

e. Mempersiapkan alat-alat yang akan digunakan membantu proses pembelajaran

f. Membaca dengan baik pedomanpedoman yang diberikan oleh Departemen pendidikan dalam menyusun perencanaan agar mampu 
nanti melakukan pembelajaran sesuai harapan

g. Menyusun materi pembelajaran

\section{Pelaksanaan Tindakan I}

a. Membawa semua persiapan ke kelas

b. Memulai pelaksanaan pembelajaran dengan pembelajaran pendahuluan yaitu: mengucapkan salam, melakukan absensi, memotivasi siswa agar giat belajar, melakukan apersepsi, menyampaikan tujuan pembelajaran serta cakupan materi yang sedang diajarkan

c. Melakukan pembelajaran inti explorasi dengan cara:

1. Melibatkan peserta didik mencari informasi yang luas dan dalam tenang topik/tema materi yang akan dipelajari dengan menerapkan prinsip alam takambang jadi guru dan belajar dari aneka sumber;

2. Menggunakan beragam pendekatan pembelajaran, media pembelajaran, dan sumber belajar lain;

3. Memfasilitasi terjadinya interaksi antarpeserta didik serta antara peserta didik dengan guru, lingkungan dan sumber belajar lainnya;

4. Melibatkan peserta didik secara aktif dalam setiap kegiatan pembelajaran; dan

5. Memfasilitasi peserta didik melakukan percobaan di laboratorium, studio, atau lapangan.

d. Melakukan pembelajaran inti elaborasi dengan cara:

1 Membiasakan peserta didik membaca dan menulis yang beragam melalui tugas-tugas tertentu yang bermakna;
2 Memfasilitasi peserta didik melalui pemberian tugas, diskusi dan lainlain untuk memunculkan gagasan baru baik secara lisan maupun tertulis;

3 Memberi kesempatan untuk berpikir, menganalisis, menyelesaikan masalah dan bertindak tanpa rasa takut;

4 Memfasilitasi peserta didik dalam pembelajaran kooperatif dan kolaboratif;

5 Memfasilitasi peserta didik berkompetisi secara sehat untuk meningkatkan prestasi belajar;

6 Memfasilitasi peserta didik membuat laporan eksplorasi yang dilakukan baik lisan maupun tertulis, secara individual maupun kelompok;

7 Memfasilitasi peserta didik untuk menyajikan variasi; kerja individual maupun kelompok;

8 Memfasilitasi peserta didik melakukan pameran, turnamen, festival, serta produk yang dihasilkan;

9 Memfasilitasi peserta didik melakukan kegiatan yang menumbuhkan kebanggaan dan rasa percaya diri peserta didik.

e. Melakukan pembelajaran inti konfirmasi dengan cara:

1. Memberikan umpan balik positif dan penguatan dalam bentuk lisan, tulisan, isyarat, maupun hadiah terhadap keberhasilan peserta didik,

2. Memberikan konfirmasi terhadap hasil eksplorasi dan elaborasi peserta didik melalui berbagai sumber, 
3. Memfasilitasi peserta didik untuk memperoleh pengalaman yang bermakna dalam mencapai kompetensi dasar.

4. Berfungsi sebagai narasumber dan fasilitator dalam menjawab pertanyaan peserta didik yang menghadapi kesulitan dengan menggunakan bahasa yang baku dan benar;

5. Membantu menyelesaikan masalah;

6. Memberi acuan agar peserta didik dapat melakukan pengecekan hasil eksplorasi;

7. Memberi informasi untuk bereksplorasi lebih jauh;

8. Memberikan motivasi kepada peserta didik yang kurang atau belum berpartisipasi aktif.

f. Melakukan kegiatan pembelajaran penutup dengan cara:

1. Bersama-sama dengan peserta didik dan/atau sendiri membuat rangkuman/simpulan pelajaran;

2. Melakukan penilaian dan/atau refleksi terhadap kegiatan yang sudah dilaksanakan secara konsisten dan terprogram;

3. Memberikan umpan balik terhadap proses dan hasil pembelajaran;

4. Merencanakan kegiatan tindak lanjut dalam bentuk pembelajaran remidi, program pengayaan, layanan konseling dan/atau memberikan tugas baik tugas individual maupun kelompok sesuai dengan hasil belajar peserta didik;

5. Menyampaikan

rencana pembelajaran pada pertemuan berikutnya. g. Mengakhiri pembelajaran dengan mengucapkan salam penutup

h. Melakukan penilaian proses

\section{Observasi/Pengamatan Siklus I}

Pengamatan dilakukan setelah proses pembelajaran dilaksanakan dalam 3 kali pertemuan dengan memberikan tes prestasi belajar. Dalam pengamatan ini peneliti mengawasi siswa dengan ketat agar tidak ada siswa yang bekerjasama dalam mengerjakan soal.Hasil pengamatan pada siklus I penelitian sampaikan pada tabel berikut.

Tabel 01. Prestasi Belajar Siswa Kelas VIII E Semester 2 Tahun Pelajaran 2016/2017, Siklus I

\begin{tabular}{cc}
\hline Jumlah Nilai & 2.946 \\
\hline Rata-rata (Mean) & 79,62 \\
\hline $\begin{array}{c}\text { KKM (Kriteria Ketuntasan } \\
\text { Minimal) }\end{array}$ & 80,00 \\
\hline $\begin{array}{c}\text { Jumlah Siswa yang Mesti } \\
\text { Diremidi }\end{array}$ & 15 \\
\hline $\begin{array}{c}\text { Jumlah Siswa yang Perlu } \\
\text { Diberi Pengayaan }\end{array}$ & 22 \\
\hline Prosentase Ketuntasan Belajar & $59,46 \%$ \\
\hline
\end{tabular}

\section{Refleksi Siklus I}

Refleksi merupakan kajian secara menyeluruh tindakan yang telah dilakukan berdasarkan data yang telah terkumpul, kemudian dilakukan evaluasi guna menyempurnakan tindakan.

Analisis kuantitatif Prestasi belajar siswa siklus I

1. Banyak kelas $(\mathrm{K})=1+3,3 \times \log (\mathrm{N})=$ 6,18

2. Rentang kelas $(r)=20$

3. Panjang kelas interval (i) $=\frac{r}{K}=\frac{20}{6}=$ $3,33 \rightarrow 4$

Mengikuti penegasan Depdiknas (2011: 25) bahwa pada Bab IV direkam 
kegiatan masing-masing siklus diserta data lengkap beserta aspek-aspek yang direkam/diamati. Rekaman itu menunjukkan adanya perubahan akibat tindakan yang diberikan. Pada refleksi di akhir setiap siklus berisi penjelasan tentang aspek keberhasilan dan kelemahan yang terjadi dalam bentuk grafik. Kemukakan adanya perubahan/kemajuan/perbaikan yang terjadi pada diri siswa, lingkungan kelas, guru sendiri, minat, motivasi belajar dan hasil belajar. Untuk bahan dasar analisis dan pembahasan kemukakan hasil kelemahan siklus ke dalam ringkasan tabel/grafik. Data tabel/grafik rangkuman itu akan dapat memperjelas perubahan yang terjadi disertai pembahasan secara rinci dan jelas. Selain penegasan dari Depdiknas tersebut pendapat ahli juga sama dengan pendapat tersebut. Suharsimi Arikunto, Suhardjono, Supardi (2006: 83) menjelaskan bahwa pada Bab IV jika terdapat kelemahan- kelemahan dilakukan perbaikan di siklus II.

\section{Siklus II}

\section{Rencana Tindakan II}

Hasil yang didapat dari kegiatan perencanaan meliputi:

a. Menyusun RPP mengikuti alur metode/model

b. Menyiapkan bahan-bahan pendukung pembelajaran

c. Membaca teori-teori tentang metode penerapan model Kuantum untuk dapat dilaksanakan dengan benar di lapangan

d. Membuat soal-soal penilaian yang berhubungan dengan kompetensi siswa

e. Mempersiapkan alat-alat yang akan digunakan membantu proses pembelajaran f. Membaca dengan baik pedomanpedoman yang diberikan oleh Departemen pendidikan dalam menyusun perencanaan agar mampu nanti melakukan pembelajaran sesuai harapan

g. Menyusun materi pembelajaran

\section{Pelaksanaan Tindakan II}

a. Membawa semua persiapan ke kelas

b. Memulai pelaksanaan pembelajaran dengan pembelajaran pendahuluan yaitu: mengucapkan salam, melakukan absensi, memotivasi siswa agar giat belajar, melakukan apersepsi, menyampaikan tujuan pembelajaran serta cakupan materi yang sedang diajarkan

c. Melakukan pembelajaran inti explorasi

d. Melakukan pembelajaran inti elaborasi

1. Membiasakan peserta didik membaca dan menulis yang beragam melalui tugas-tugas tertentu yang bermakna;

2. Memfasilitasi peserta didik melalui pemberian tugas, diskusi dan lainlain untuk memunculkan gagasan baru baik secara lisan maupun tertulis;

3. Memberi kesempatan untuk berpikir, menganalisis, menyelesaikan masalah dan bertindak tanpa rasa takut;

4. Memfasilitasi peserta didik dalam pembelajaran kooperatif dan kolaboratif;

5. Memfasilitasi peserta didik berkompetisi secara sehat untuk meningkatkan prestasi belajar;

6. Memfasilitasi peserta didik membuat laporan eksplorasi yang dilakukan baik lisan maupun 
tertulis, secara individual maupun kelompok;

7. Memfasilitasi peserta didik untuk menyajikan variasi; kerja individual maupun kelompok;

8. Memfasilitasi peserta didik melakukan pameran, turnamen, festival, serta produk yang dihasilkan;

9. Memfasilitasi peserta didik melakukan kegiatan yang menumbuhkan kebanggaan dan rasa percaya diri peserta didik.

10. Melakukan pembelajaran inti konfirmasi dengan cara:

11. Memberikan umpan balik positif dan penguatan dalam bentuk lisan, tulisan, isyarat, maupun hadiah terhadap keberhasilan peserta didik,

12. Memberikan konfirmasi terhadap hasil eksplorasi dan elaborasi peserta didik melalui berbagai sumber,

13. Memfasilitasi peserta didik untuk memperoleh pengalaman yang bermakna dalam mencapai kompetensi dasar.

14. Melakukan kegiatan pembelajaran penutup

15. Menyampaikan

rencana pembelajaran pada pertemuan berikutnya.

16. Mengakhiri pembelajaran dengan mengucapkan salam penutup

17. Melakukan penilaian proses

\section{Observasi/Pengamatan II}

Hasil pengamatan pada Siklus II penelitian sampaikan pada tabel berikut.
Tabel 02. Prestasi Belajar Siswa Kelas VIII E Semester 2 Tahun Pelajaran 2016/2017. Siklus II

\begin{tabular}{lcc}
\hline Jumlah Nilai & $\mathbf{3 . 0 9 2}$ & $\mathbf{3 . 0 9 2}$ \\
\hline Rata-rata (Mean) & $\mathbf{8 3 , 5 7}$ & $\mathbf{8 3 , 5 7}$ \\
\hline $\begin{array}{l}\text { KKM (Kriteria Ketuntasan } \\
\text { Minimal) }\end{array}$ & 80,00 & 80,00 \\
\hline Jumlah Siswa yang Mesti Diremidi & 3 & 3 \\
\hline $\begin{array}{l}\text { Jumlah Siswa yang Perlu Diberi } \\
\text { Pengayaan }\end{array}$ & 34 & 34 \\
\hline Prosentase Ketuntasan Belajar & $98,89 \%$ & $98,89 \%$ \\
\hline
\end{tabular}

\section{Refleksi Siklus II}

Analisis kuantitatif Prestasi belajar siswa siklus II

1. Rata-rata (mean) 83,57

2. Modus $=80,00$

3. Banyak kelas $(\mathrm{K})=1+3,3 \times \log 37=$ $6,18 \rightarrow 6$

4. Rentang kelas $(r)=14$

5. Panjang kelas interval (i) $=\frac{r}{K}=\frac{14}{6}=$ $2,33 \rightarrow 3$

Dari data awal yang diperoleh dengan rata-rata 75,78 menunjukkan bahwa kemampuan siswa kelas VIII E Semester 2 dalam mata pelajaran Bahasa Indonesia dalam menulis ceita pendek masih sangat rendah mengingat kriteria ketuntasan belajar siswa untuk mata pelajaran ini di SMP Negeri 1 Denpasar adalah 80,00 . Dengan nilai yang sangat rendah seperti itu maka peneliti mengupayakan untuk dapat meningkatkan prestasi belajar siswa menggunakan penerapan model pembelajaran Kuantum Akhirnya dengan penerapan model pembelajaran Kuantum yang benar sesuai teori yang ada, maka peningkatan rata-rata prestasi belajar Bahasa Indonesia dalam Menulis Ceita Pendek siswa kelas VIII E pada siklus I meningkat dan mencapai rata-rata. 79,62 Namun rata-rata tersebut belum maksimal karena masih lagi 15 
orang siswa yang harus diremedi atau dibawah KKM. Sedangkan prosentase ketuntasan belajar mereka baru mencapai $59,46 \%$. Hal tersebut terjadi akibat penerapan model pembelajaran Kuantum belum maksimal, penerapan model tersebut baru dicobakan sehingga guru masih belum mampu melaksanakannya sesuai alur teori yang benar.

Pada siklus ke II perbaikan prestasi belajar siswa diupayakan lebih maksimal, peneliti membuat perencanaan yang lebih baik, menggunakan alur dan teori dari penerapan model Kuantum dengan benar dan lebih maksimal. Peneliti giat memotivasi siswa agar giat belajar, memberi arahan-arahan, menuntun mereka untuk mampu menguasai materi pelajaran pada mata pelajaran Bahasa Indonesia dalam menulis cerita pendek lebih optimal. Akhirnya dengan semua upaya tersebut peneliti mampu meningkatkan prestasi belajar siswa pada siklus II menjadi ratarata 87,57 Upaya-upaya yang maksimal tersebut menuntun kepada penelitian bahwa penerapan model pembelajaran Kuantum mampu meningkatkan prestasi belajar Bahasa Indonesia dalam menulis cerita pendek pada siswa kelas VIII E Semester 2 Tahun Pelajaran 2016/2017

\section{Simpulan}

Bertitik tolak dari pemicu rendahnya prestasi belajar Bahasa Indonesia dalam menulis cerita pendek penyebabnya pada faktor-faktor seperti model pembelajaran yang digunakan guru, sehingga penggunaan atau penggantian model pembelajaran perlu dilakukan, sehingga peneliti mencoba menerapkan model pembelajaran Kuantum dalam upaya untuk dapat memecahkan permasalahan yang ada yaitu rendahnya prestasi belajar Bahasa Indonesia dalam menulis cerita pendek

Bertumpu pada rendahnya prestasi belajar Bahasa Indonesia dalam menulis cerita pendek yang sudah disampaikan pada latar belakang masalah, maka penerapan model pembelajaran Kuantum diupayakan untuk dapat mengatasi masalah tersebut dan juga dapat mencapai tujuan penelitian ini yaitu meningkatnya prestasi belajar. Bahasa indonesia dalam menulis cerita pendek. Peningkatan yang dicapai sudah dipaparkan dengan jelas pada akhir analisis. Dari hasil penelitian yang disampaikan di Bab IV dan melihat semua data yang telah disampaikan, maka tujuan penelitian yang disampaikan di atas dapat dicapai dengan bukti sebagai berikut:

Kenaikan prestasi belajar siswa dapat dilihat dari bukti-bukti berikut:

a. Dari data awal ada 27 siswa mendapat nilai dibawah KKM dan pada siklus I menurun menjadi 15 siswa dan siklus II hanya 3 siswa mendapat nilai di bawah KKM.

b. Dari rata-rata awal 75,78 naik menjadi 79,62 pada siklus I dan pada siklus II naik menjadi 83,57

c. Dari data awal siswa yang tuntas hanya 10 siswa sedangkan pada siklus I menjadi lebih banyak yaitu 22 siswa dan pada siklus II menjadi cukup banyak yaitu 34 siswa.

Dari semua data pendukung pembuktian pencapaian tujuan pembelajaran dapat disampaikan bahwa penerapan model pembelajaran Kuantum dapat memberi jawaban yang diharapkan sesuai tujuan penelitian ini yaitu dapat meningkatkan prestasi belajar bahasa indonesia dalam menulis cerita pendek 
pada siswa kelas VIII E Semester 2 SMP Negeri 1 Denpasar Tahun Pelajaran 2016/2017 Semua ini dapat dicapai adalah akibat kesiapan dan kerja keras peneliti dari sejak perencanaan, review hal-hal yang belum bagus bersama teman-teman guru, penyusunan kisi-kisi dan instrumen penelitian, penggunaan sarana, data sampai pada pelaksanaan penelitian yang maksimal.

\section{Saran}

Berdasarkan pembahasan diatas yang sudah disimpulan dari hasil penelitian, bahwa penerapan model pembelajaran Kuantum dapat meningkatkan prestasi belajar bahasa indonesia dalam menulis cerita pendek, pada siswa kelas VIII E Semester 2 SMP Negeri 1 Denpasar Tahun Pelajaran 2016/2017 dapat disampaikan saran-saran sebagai berikut:

1. Dalam melaksanakan proses pembelajaran pada mata pelajaran bahasa indonesia dalam menulis cerita pendek, penggunaan model pembelajaran Kuantum terbukti dapat meningkatkan kerjasama, berkreasi, bertindak aktif, bertukar informasi, mengeluarkan pendapat, bertanya, berdiskusi, berargumentasi dan lain-lain.

2. Walaupun penelitian ini sudah dapat membuktikan efek utama dari model pembelajaran Kuantum dalam meningkatkan prestasi belajar bahasa indonesia dalam menulis cerita pendek, sudah pasti dalam penelitian ini masih ada halhal yang belum sempurna dilakukan, oleh karenanya kepada peneliti lain yang berminat meneliti topik yang sama untuk meneliti bagian-bagian yang tidak sempat diteliti.

3. Selanjutnya untuk adanya penguatan-penguatan, diharapkan bagi peneliti lain untuk melakukan penelitian lanjutan guna verifikasi data hasil penelitian.

\section{DAFTAR PUSTAKA}

Abdul.2002.http://:www.scribd.com/doc/9 037208/

Agus Yuwono. Jurnal Lingua V/1 Januari 2009. Optimalisasi Web Internet Sebagai Usaha Peningkatan Kemampuan Menulis Karya Ilmiah Bagi Mahasiswa Prodi PBSJ Semester VIII FBS Universitas Negeri Semarang.

Anastasi, Anne. 1976. Psychological Testing. Fifth Edition. New York: Macmillan Publishing Co., Inc.

Arikunto, Suharsimi; Suhardjono; Supardi. 2006. Penelitian Tindakan Kelas. Jakarta: PT Bumi Aksara.

Aryana, Wayan. 2003. Pengaruh Motivasi Belajar terhadap Prestasi Belajar IPA pada Siswa SMP Negeri 1 Denpasar. Ringkasan Hasil Penelitian yang Disampaikan dalam Seminar Hasil Penelitian Dosen Kopwil VIII, Tanggal 22-24 September 2003.

Azwar, Saifuddin. 2003. Penyusunan Skala Psikologi. Yogyakarta: Pustaka Pelajar.

Dahar, Ratna Wilis. 1989. Teori-Teori Belajar. Jakarta: Penerbit Erlangga.

Depdikbud. 1984/1985. Program Akta Mengajar V-B Komponen Dasar Kependidikan: Penilaian Program Pendidikan. Jakarta: Universitas Terbuka.

Depdikbud. 1994. Petunjuk Pelaksanaan Proses Belajar-Mengajar. Jakarta: Direktorat Pendidikan Menengah Umum. 
Depdikbud. 1996. Petunjuk Teknis Mata Pelajaran IPS-Sejarah. Jakarta: Direktorat Pendidikan Menengah Umum.

Dimyati dan Mudjiono. 2001. Belajar dan Pembelajaran. Jakarta: Dirjen Dikti.

Djamarah, Syaful Bahri. 2002. Prestasi Belajar dan Kompetensi Guru. Surabaya: Usaha Nasional.

Fernandes, H.J.X. 1984. Testing and Measurement. Jakarta. National Education Planning, Evaluation and Curriculum Development.

Firdaus, Muhammad Irfan. Makna Ungkapan "Pengalaman adalah guru terbaik".Tersediahttp://maknahidup.b logdetik.com/2009/11/01/maknaungkapan-pengalaman-adalah-guruterbaik/

Fraenkel, Jack R. and Norman E. Wallen. 1993. How to Design and Evaluate Research in Education. Second Edition. New York: McGraw-Hill, Inc.

Gagne, Robert M. 1977. The Conditions of Learning. Third Edition. New York: Holt, Reinhart and Winston.

Gay, L. R. 1987. Educational Research: Competencies for Analysis and Application. Seventh Edition. Columbus, Ohio: Merrill Publishing Company.

Good, Thomas L. \& Jere E. Brophy. 1990. Educational Psychology, A Realistic Approach. New York: Longman.

Gregory, Robert J. 2000. Psychological Testing: History, Principles, and Applications. Boston: Allyn and Bacon.

Gronlund, Norman E. 1982. Constructing Achievement Tests. Third Edition.
London: Prentice-Hall, Inc., Englewood Cliffs.

Hadi, Munirul. 2009. Tesis. Peningkatan Kemampuan Menulis Puisi Pada Siswa Kelas V SDN Teguhan 2 Kecamatan Paron Melalui Penerapan Model Pembelajaran Berbasis Masalah Tahun Pelajaran 2008/2009. Program Studi Pendidikan Bahasa Indonesia. Program Pascasarjana Universitas Sebelas Maret Surakarta

Hamalik, Oemar. 2002. Psikologi Belajar dan Mengajar. Bandung: Sinar Baru.

Herrhyanto, Nar dan Hamid, Akib. 2006. Statistika Dasar. Jakarta: Universitas Terbuka.

Hilke, Eileen Veronica. 1998. Fastback Cooperative Learning. New York: McGraw-Hill, Inc.

http://id.wikipedia.org/wiki/Cerita_pendek. Inten, I Gede. 2004. Pengaruh Model Pembelajaran dan Pengetahuan Awal Siswa Terhadap Prestasi Belajar PKn dan Sejarah pada Siswa Kelas II di SMU Laboratorium IKIP Negeri Singaraja. Tesis. Program Pascasarjana IKIP Negeri Singaraja.

Lickona, Thomas. 1992. Educating For Character. How Our Schools Can Teach Respect and Responsibility. New York: Bantam Books.

Lie, Anita. 2002. Cooperative Learning: Mempraktikkan Cooperative Learning di Ruang-Ruang Kelas. Jakarta: PT Gramedia Widiasarana Indonesia.

Miles, Matthew, B. Dan A. Michael Hubberman. 1992. Analisis Data Kualitatif. 